\title{
Diversity and Abundance of Arbuscular-Mycorrhizal Fungus Spores in Tropical Forest and Pasture ${ }^{1}$
}

\author{
Chris Picone ${ }^{2}$ \\ Department of Biology, University of Michigan, Ann Arbor, Michigan 48109, U.S.A.
}

\begin{abstract}
As Neotropical forests are increasingly converted to agriculture (especially pastures), little is known about the impacts on microbial biodiversity. To assess such impacts, I compared spore abundance and diversity of arbuscular mycorrhizal fungi (AMF) in soils from lowland evergreen forests and pastures in Nicaragua and Costa Rica. Species composition, dominance-diversity curves, and Simpson's diversity indices were similar for both forest and pasture soils. Of 28 distinct fungus morphospecies, 11 produced more spores in pasture, while only 1 produced more spores in forest. According to species-accumulation curves, local AMF species richness did not significantly decline following conversion of forest to pasture. Because pastures contained a surprising abundance and diversity of AMF spores compared to native forest, a lack of mycorrhizal fungi is unlikely to limit plant succession, restoration, or reforestation in the pastures studied. At the regional scale, however, species-accumulation curves showed significantly greater gamma (G) diversity of spores in forest. In addition to these trends in diversity, species that sporulated more in pasture tended to have small spores, while the one species that sporulated more in forest had the largest spores. Similarly, only largespored fungi $(>300 \mu \mathrm{m})$ showed any seasonal variation in spore abundance, being more common in the wet season.
\end{abstract}

\section{RESUMEN}

Mientras que se convierten bosques tropicales hacía agricultura, especialmente pastos, se sabe poco de los impactos para diversidad microbial. Para saber dicho impactos, comparé abundancia y diversidad de esporas de hongos micorizales arbusculares (HMA) en suelo de bosque tropical siempre verde y de pasto en Nicaragua y Costa Rica. Comunidad de especies, curvas de dominancia-diversidad, y indices de diversidad (Simpson) eran similares en pasto y bosque. De 28 "morfo-especies," 11 producieron más esporas en pasto, mientras que sólo una especie tenía más esporas en bosque. Según curvas de acumulación de especies, diversidad local no declinódespues de la conversión de bosque a pasto. Porqué pasto tenía una gran abundancía y diversidad de esporas, entonces succesión, restauración, y reforestación de pastos no debe ser inhibidas por falta de micorrizas. Sin embargo, curvas de acumulación de especies por la región mostraron que la diversidad de esporas de HMA es más alta en bosque. Además de estos cuestiones de diversidad, las especies que producieron más esporas en pasto tenían esporas pequeños, mientras que la especie que fue más abundante en bosque tenía las esporas más grandes. También, solamente especies con esporas grandes (>300 $\mu$ m) feuron más abundantes en la estación lluviosa.

Key words: Costa Rica; deforestation; Glomales; lowland humid tropics; Nicaragua; restoration; seasonality; spores; succession.

As HUMANS INCREASINGLY MANIPULATE ECOSYSTEMS, what are the impacts on the biodiversity of different taxa and functional groups? This urgent question has received much attention in the tropics, where deforestation and modern agriculture most threaten biodiversity. While tropical studies have documented losses in the diversity of plants, vertebrates, and arthropods (e.g., Lavelle \& Pashanasi 1989, Wilson 1992, Perfecto et al. 1997), microorganisms have been relatively ignored (Lodge et

\footnotetext{
1 Received 12 November 1998; revision accepted 10 September 1999.

${ }^{2}$ Current address: The Land Institute, 2440 East Water Well Road, Salina, Kansas 67401; e-mail: picone@ midusa.net
}

al. 1996, Giller et al. 1997). To help understand the impacts of agricultural conversion on soil microbes, I compared diversity of arbuscular mycorrhizal fungi in both lowland evergreen forest and pasture.

Arbuscular mycorrhizae (AM) are mutualisms between plant roots and zygomycete fungi in the Glomales (Morton \& Benny 1990). The AM fungi (AMF) provide mineral nutrients to their plant hosts in exchange for carbohydrates. Although the fungi comprise only 150-170 asexual morphotypes, or species, this mutualism is found in the roots of 70 to 80 percent of terrestrial plant species (Trappe 1987). In nutrient-poor soils of the humid tropics, many late-successional trees are obligately dependent on AMF and only grow beyond seed 
reserves if infected. Therefore, studying AM ecology would improve understanding of tropical forest functioning, especially of plant succession and reforestation in old pasture. If either abundance or diversity of AMF is reduced in old pastures, then succession, restoration, or reforestation could be inhibited. (Janos 1980, 1988; Sieverding 1989; van der Heijden et al. 1998b).

To determine the effects of tropical forest conversion on AMF, previous studies have compared spore counts in forests and disturbed habitats. In tropical forest, deforestation initially reduces the number of soil spores (Alexander et al. 1992, Wilson et al. 1992) due to the susceptibility of mycorrhizae to disturbance (Janos 1996). Because the old pastures in my study were severely disturbed by burning, grazing, and soil compaction, they were expected to have low spore counts. Spore counts, however, can recover rapidly after tropical deforestation if mycorrhizal host plants are present (Mason et al. 1992, Wilson et al. 1992). Spores are equally or more abundant in pasture compared to dry forest (Jasper et al. 1991, Johson \& Wedin 1997, Allen et al. 1998) or humid secondary forest (Fisher et al. 1994). My study presents the first comparison of mycorrhizal spore counts in pasture and mature, lowland evergreen forest.

In addition to altering the abundance of spores, converting tropical forest to pasture could reduce the diversity of AMF. Because changes in the host plant community generally alter the AMF community (e.g., Sieverding 1989, Bever et al. 1996), and because host plant diversity is much lower in pasture than in native forest, AMF diversity may also decline. As shown in previous studies, pastures can become dominated by a few AMF species when compared to Mexican dry forest (Allen et al. 1998) or Australian jarrah forest (Jasper et al. 1991). In Colombia, AMF species richness decreased in lowdiversity agroecosystems relative to natural systems. Johnson and Wedin (1997), however, found similar species richness in Costa Rican dry forest and monodominant grassland. Likewise, African tree plantations were found to have more AMF species than native moist forest (Wilson et al. 1992).

Unfortunately, none of these previous studies presented species-accumulation curves. Such curves are critical because comparing the average species richness between habitats can provide deceptive results if inadequate numbers of samples are collected (Stout \& Vandermeer 1975). A habitat with high beta $(\beta)$ diversity (turnover between samples) may have in reality the greatest total number of species, but species richness may appear low if few samples are examined. Indeed, Johnson and Wedin (1997) reported that AMF species richness was similar between forest and invasive grassland, but also that $\beta$ diversity was greater in forest. In that study, further sampling probably would have found higher species richness in forest, according to the theory behind species-sample curves (Stout \& Vandermeer 1975). My study presents the first use of speciesaccumulation curves to compare AMF diversity between tropical habitats.

\section{MATERIALS AND METHODS}

STUDY SITES.- - This study was conducted in lowland evergreen forests and pastures at 10 to $30 \mathrm{~m}$ elevation in eastern Nicaragua and Costa Rica. Regional precipitation is $2600-3800 \mathrm{~mm} / \mathrm{yr}$, with a dry season from February to May. All soils used were highly weathered, acidic clay Ultisols; $\mathrm{pH}$ ranged from 3.9 to 4.7 in forest and 4.8 to 5.6 in pasture; available $\mathrm{P}$ ranged from 4 to $7 \mathrm{ppm} ; \mathrm{Fe}$ levels reached $310 \mathrm{ppm}$ in some sites; and organic matter (top $15 \mathrm{~cm}$ ) varied from 5 to 10 percent (results from the National Agricultural University, Managua, Nicaragua, and CATIE, Turrialba, Costa Rica). Bulk density was $0.65 \mathrm{~g} / \mathrm{ml}$ in forest and $0.80 \mathrm{~g} / \mathrm{ml}$ in pasture (Picone, pers. obs.). Common forest vegetation included: Pentaclethra macroloba, Carapa guianensis, Dipterix panamensis, Simarouba amara, Vochysia ferruginea, Dalbergia tucurensis, and several palms (Astrocaryum alatum, Bactris spp., Geonoma congesta, and Welfa georgii). All pastures were dominated by grasses (Poaceae), especially $I s-$ chaemum ciliare, as well as Hyparrhenia rufa and Paspalum spp. Less abundant plants in pasture included Mimosa pudica, Solanum sp., and members of the Cyperaceae, Lamiaceae, and Melastomataceae.

Soil was collected at seven locations: six near Bluefields, Nicaragua, and one near Guápiles, Costa Rica (Fig. 1). Except for the primary forest at Kurinwás, all of the Nicaraguan forests were damaged by Hurricane Joan in 1988; however, all primary forest species had regenerated by the time of sampling (Vandermeer et al. 1995). The forest at the Neguev settlement, Costa Rica, had been selectively logged for $D$. panamensis about ten years prior to sampling, but was otherwise mature. Pastures at Loma de Mico were particularly old ( $>40 \mathrm{yr}$ ) and large $\left(20 \mathrm{~km}^{2}\right)$, while pastures at other sires were cleared 10-20 years prior to sampling and occupied at least ten hectares. The site Finca Meza was unique because it contained alluvial pastures that had been abandoned for more than five years. 


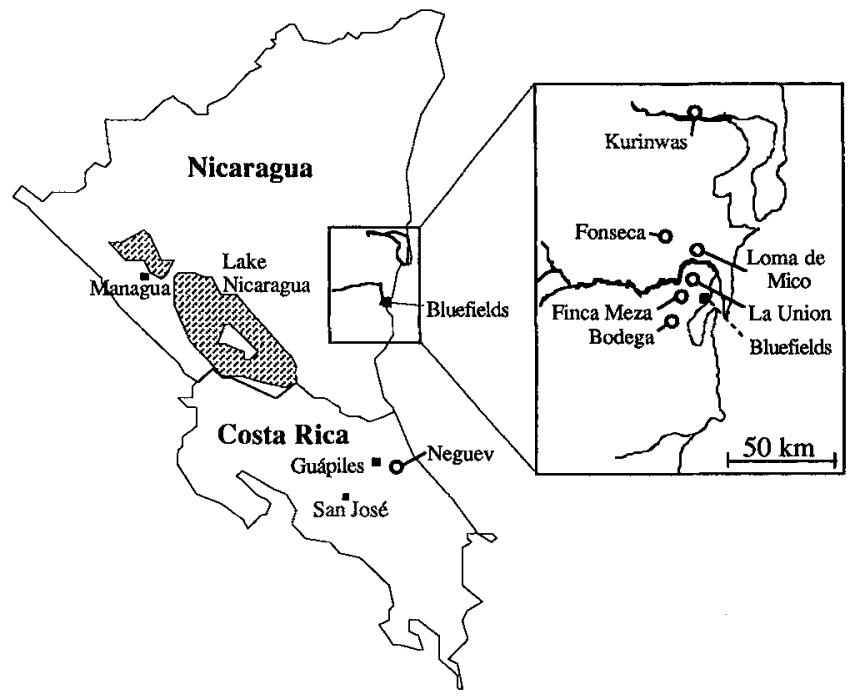

FIGURE 1. Sites sampled for AMF spores (open circles) and nearby cities (closed squares). All sites include pasture and forest, except Kurinwás, which only had forest. Composite samples from Kurinwás, Fonseca, Bodega, and Loma de Mico were analyzed together as one "miscellaneous" site because each had only one or two samples.

Soll SAMPLING.-Because this study included samples collected from 1993 through 1996, soil was collected and processed differently among sites; however, within each site pasture and forest, sampling was consistent. As summarized in Table 1, I collected samples along transects and either analyzed each sample individually ("single samples"), or analyzed a mix of all subsamples from a transect ("composite samples"). Because spores can be heterogeneously distributed (St. John \& Koske 1988, Picone 1996), soil composites provided more accurate surveys than single samples. The site Finca Meza was assessed with both single and composite sampling strategies. Only one or two composites were collected in each of four sites (Bodega, Fonseca, Loma de Mico, and Kurinwás), so I pooled their data and analyzed them together as one "miscellaneous" site. At all sites, the distance from pasture samples to nearest forest edge was at least 30 $\mathrm{m}$ and often reached several hundred meters. Distances between samples varied most at Loma de Mico, because those samples were part of a preliminary study on the spatial heterogeneity of soil spores (Picone 1996).

Because spore counts of some AMF can vary seasonally, I collected soil in both wet and dry seasons at some sites (Table 1). All samples from the wer season were gathered from July to August, and

TABLE 1. Summary of methods used for sampling soil. Note that $\mathrm{N}=$ the number of soil samples, which were analyzed either individually ("single samples") or as a composite mix of subsamples ("composite"). Composites consisted of four to ten subsamples, each 60-175 $\mathrm{ml}$, spaced 3-50 $\mathrm{m}$ apart within a sample, depending on the site.

\begin{tabular}{|c|c|c|c|c|c|c|c|}
\hline & Site & $\begin{array}{c}N= \\
\text { (For, Pas) }\end{array}$ & $\begin{array}{l}\text { Sample } \\
\text { volume } \\
\text { (ml) }\end{array}$ & $\begin{array}{c}\text { Sample } \\
\text { volume* } \\
\text { sieved }(\mathrm{ml})\end{array}$ & $\begin{array}{l}\text { Depth } \\
(\mathrm{cm})\end{array}$ & $\begin{array}{l}\text { Distance } \\
\text { between } \\
\text { samples } \\
(\mathrm{m})\end{array}$ & $\begin{array}{c}\text { Seasons } \\
\text { sampled }\end{array}$ \\
\hline \multirow[t]{3}{*}{ Single samples } & Neguev & 6,6 & 300 & 60 & 6 & $>15$ & Wet \\
\hline & Loma de Mico & 24,24 & 300 & 300 & 1.5 & $0.03-300$ & Wet \\
\hline & Finca Meza & 12,12 & 400 & 100 & 10 & $5-50$ & Wet \\
\hline \multirow{4}{*}{$\begin{array}{l}\text { Composite sam- } \\
\text { ples }\end{array}$} & & & & & & & \\
\hline & Finca Meza & 5,4 & $480-1200$ & 200 & 6 & ca 50 & Wet/Dry \\
\hline & La Union & 6,7 & $240-700$ & 200 & 6 & ca 50 & Wet/Dry \\
\hline & Miscellaneous & 3,4 & $400-1000$ & $100-300$ & 6 & $>5000$ & Wet/Dry \\
\hline
\end{tabular}

*Volume sieved was measured as water displaced $(1 \mathrm{ml}=c a 1.6 \mathrm{~g}$ fresh wt. $=1.0 \mathrm{~g}$ dry wt). 
for the dry season, from March to April. Sample volume, number, and distances varied within sites at different seasons, so only spore abundance, not species diversity, were compared between seasons.

Srore analysis. - As with the design for collecting soil, methods of extracting AMF spores varied among sites but were consistent between pasture and forest samples within sites. Instead of using soil volume from cores, I measured soil volume as water displaced by each sample (Table $1 ; 1 \mathrm{ml}$ soil $=c a$ $1.6 \mathrm{~g}$ fresh wt. $=1.0 \mathrm{~g}$ dry wt.). Spores then were wet-sieved and decanted according to methods adapted from Janos (1984). Each swirling soil suspension was poured through two mesh sieves, 700 and $45 \mu \mathrm{m}$. Up to 40 percent of the spores can be left in the sediment from the first sieving (Picone, pers. obs.), so the sediment was re-suspended in swirling water and re-sieved (this step was omitted for the single samples from Loma de Mico).

Soil caught on the small sieve then was centrifuged in a refrigerated $20 / 60$ percent sucrose gradient (Daniels \& Skipper 1982). At the first two sites tested (Loma de Mico and Neguev), soil was centrifuged at 2000 to $3000 \mathrm{rpm}$ for two minutes. All other samples were spun at 450 and $900 \mathrm{rpm}$ for one minute at each speed. These lower speeds sufficiently separated spores from soil while losing few spores to the pellet. Samples were stored in 0.05 percent sodium azide if they were not examined immediately in $0.5-\mathrm{cm}$ gridded petri dishes. Each entire sample first was examined thoroughly for distinct spore types that were large or rare. Then grid squares were subsampled randomly to estimate the quantity of small, numerous spores. For every sample, spore identification was verified at 100 to $1000 \times$. I classified spore types based on voucher specimens from the International Collection of Arbuscular and Vesicular-Arbuscular Mycorrhizal Fungi (University of West Virginia, Morgantown, West Virginia), as well as Schenck and Perez (1990). For species generally found as sporocarps (Glomus rubiformis, G. clavisporum, and Sclerocystis coremioides), the sporocarps were counted instead of individual spores.

Statistical analyses. - To determine whether the spores of each AMF species were more abundant in forest or pasture soil, I tested soil habitat (pasture vs. forest) as a grouping factor both within and across all sites. Within each of the five sites (Loma de Mico, Neguev, Finca Meza, La Union, and miscellaneous), I compared the number of spores per $100-\mathrm{ml}$ soil from pasture and forest with a one-way Kruskal-Wallis test (Systat v. 5.2.1; Wilkinson et al. 1992). To test each AMF species across all five sites, I transformed spore counts to ranks and tested them with a two-way, nonparametric bootstrap resampling test (available from the author). The resampling test functioned like a twoway ANOVA, because it accounted for variation due to one factor (site) while determining significance of another factor (soil habitat). This test first eliminated variability caused by site itself, or by the different methods used at each site, by generating an array of residuals. That is, each sample's rank was subtracted from the mean rank for the site. The mean of the residuals at all sites was therefore equal to zero. Using those residuals, the test calculated the difference in means from pasture and forest soil at each site, and then averaged those differences across the five sires. By randomly resampling the data within each site 10,000 times, a probability distribution was generated for the average difference between pasture and forest, which determined statistical significance of soil habitat. In addition, I evaluated the resampling test with a mixed-model ANOVA (site $\times$ soil habitat), which generally corroborated the resampling test; however, even with rank transformed data, the assumptions for ANOVA were severely violated, so only results from the resampling test are presented.

Seasonality of spore counts was tested similarly for each fungus species. Within the three sites that had both wet and dry season data, I tested rank transformed spore counts with the two-way, nonparametric resampling test (soil habitat $X$ season). Then, the factor season was tested across all three sites by resampling the residuals in a three-way analysis (soil habitat $\times$ site $\times$ season). Again, resampling results were generally consistent with fixed-effects ANOVA (soil habitat $\times$ season) and mixed-model ANOVA (soil habitat $\times$ site $\times$ season).

Seasonality of spore production determined which statistical test was appropriate for the comparisons of pasture and forest soil at each site. As noted above, I generally used Kruskal-Wallis tests to compare pasture and forest spore counts within each site; however, in three cases (Appendix 1), seasonality confounded the significance of soil habitat. In those cases, soil habitat was not a significant factor with the one-way Kruskal-Wallis test, but soil was significant with the two-way resampling test (season $X$ soil habitat), which removed variation due to seasonality. Therefore, significance values in those three cases are reported from the two- 
way test. In all other cases, results from both statistical tests were identical.

Diversity of AMF spores in pasture and forest were compared both within sites (locally) and among sites (regionally). First, within each site, alpha $(\alpha)$ diversity was assessed as the average number of species encountered per soil sample. Beta diversity was compared in pasture and forest by using Sørenson's similarity indices (Magurran 1988) for paired comparisons between samples. To estimate species richness at each site, I used speciesaccumulation curves. These curves were generated with a bootstrap resampling program that calculated the average cumulative number of species found in one to $N$ samples (where $N=$ total no. of samples; Stout \& Vandermeer 1975).

Second, pasture and forest diversity were compared regionally, across sites, by treating each site as an independent "sample." The "miscellaneous" site was omitted from this analysis. Regional $\alpha$ diversity was the average species richness per site, and regional $\beta$ diversity was the change in species composition between paired combinations of sites. To estimate total species richness, or gamma $(\mathrm{G}) \mathrm{di}$ versity, I generated species-accumulation curves from the four study sites. Total regional species richness was calculated as the asymptote $(G)$ from the species-accumulation equation: No. of species $=\mathrm{G}^{*} \mathrm{~A} /(\boldsymbol{B}+\mathrm{A})$, where $\mathrm{G}=$ gamma diversity; $\mathrm{A}$ $=$ unit of accumulation (i.e., number of sites); and $\beta$ is the inverse of the curvature, which therefore quantifies $\beta$ diversity (J. Vandermeer, pers. comm.). Both parameters $G$ and $\beta$ were estimated with the nonlinear model function in Systat v. 5.2.1.

I then tested whether $\mathrm{G}$ diversity (i.e., the asymptotes) in forest and pasture differed statistically. I first calculated the difference in their asymptotes from the formula above, then generated a probability distribution for that difference (i.e., its probability of occurring by chance alone if pasture and forest soils were randomly distributed in the species-accumulation curve). To make the probability distribution, I calculated species-site curves for all possible combinations of the four sites with soil habitat assigned randomly to each site. Sixteen "random" estimates of $\mathrm{G}$ diversity were possible $\left(2^{4}\right)$. From that pool of 16 estimates, I calculated the difference in asymptotes from all paired combinations of $\mathrm{G}$ diversity $(N=120)$. From the distribution of those differences, I determined the significance, or probability, of the difference in asymptotes between original pasture and forest curves.

Finally, using the average spore counts at each site to measure abundance, I compared Simpson's diversity indices $\left(1 / D=1 / \Sigma p_{i}^{2}\right)$ between pasture and forest.

\section{RESULTS}

Spore abundance in pasture versus forest.-I found a total of 28 distinct spore types, although a few comprised two or three species that were difficult to distinguish. In both forest and pasture, the most common spores were Glomus "small brown," a group of similar, brown-tan-yellow Glomus spores (Table 2). The dominant fungus in this Glomus group was a brown species, $90-130 \mu \mathrm{m}$, possibly G. macrocarpum Tulasne \& Tulasne. Two other species in this Glomus complex were far less common: a smaller tan Glomus sp., possibly G. etunicatum Becker \& Gerdemann, and a larger round yellow Glomus sp. In addition to the counts of whole spores reported in Appendix 1, the G. "small brown" complex had counts of dead, empty spore walls that were four times more numerous than whole spores. The spores labeled "Glomus occultum" occasionally included one or two other similar, tiny white species, such as Acaulospora trappei Ames \& Linderman, but these were much rarer than true G. occultum. Counts of Entrophospora aff colombiana included a few rare spores of Acaulospora mellea Spain \& Schenck. The spores labeled Gigaspora sp. included large older spores in the Gigasporaceae, possibly $G$. gigantea, but as field-collected material, they could not be identified accurately.

In contrast, some species were easily distinguished morphologically, but may be genetically identical. Morton et al. (1997) showed that Acaulospora gerdemannii ( $=A$. appendicula Spain, Sieverd, \& Schenck) and Glomus leptotichum were the same species. Although placed in different families, both morphotypes can sporulate from cultures started with only a single spore. I separated these two "species" here to study the different responses of the distinct morphotypes (both were more common in pasture). Similarly, the spores labeled Acaulospora "foveata-lg." may be the same species as $A$. foveata, but here they were morphologically distinct. Spores of $A$. foveata were mostly 250-350 $\mu \mathrm{m}$, caramel to maroon, with circular pits on the spore wall, while $A$. "foveata-lg." was $450-500 \mu \mathrm{m}$, dark wine-colored to black, with fused pits forming interwoven channels over the spore wall.

Spores of most AMF were equally or more numerous in pasture than in forest (Table 2). According to the nonparametric resampling test, across all sites, 11 of the 28 spore types were significantly 
TABLE 2. Ecological trends for the 28 morphospecies compared across all sites (data for individual sites are given in
Appendix 1 ). Frequency is the total number of soil samples in which each species appeared. Soil habitat
significance was determined with a two-way resampling test (site $\times$ soil habitat) that compared rank trans-
formed spore counts. Species with significantly more spores in pasture or forest soil are indicated by PAS or
FOR, respectively. Species more abundant in the wet season are labeled WET, and were analyzed also by
resampling ranked spore counts. ${ }^{*} \mathrm{P}<0.05 ;{ }^{* * \mathrm{P}}<0.005 ; * * \mathrm{P}<0.0005$.

\begin{tabular}{|c|c|c|c|c|c|}
\hline \multirow[b]{3}{*}{ Species/Spore type } & \multirow[b]{3}{*}{ Authority } & \multicolumn{4}{|c|}{ All sites combined } \\
\hline & & \multicolumn{2}{|c|}{ Frequency } & \multirow[b]{2}{*}{$\begin{array}{l}\text { Soil habitat } \\
\text { signif. }\end{array}$} & \multirow[b]{2}{*}{$\begin{array}{l}\text { (3 sites) scason } \\
\text { signif. }\end{array}$} \\
\hline & & $\begin{array}{l}\text { FOR } \\
N=56\end{array}$ & $\begin{array}{l}\text { PAS } \\
V=57\end{array}$ & & \\
\hline \multicolumn{6}{|l|}{ Acaulosporaceae } \\
\hline Acaulospora foveata & Trappe $\&$ Janos & 51 & 51 & NS & WE $\Gamma^{* * *}$ \\
\hline $\begin{array}{l}\text { Entrophospora aff colombi- } \\
\text { ana }\end{array}$ & Spain \& Schenck & 22 & 48 & PAS $^{* * *}$ & NS \\
\hline A. tuberculata & Janos \& Trappe & 16 & 30 & PAS* & NS \\
\hline A. gerdemannii & Shenck $\&$ Nicolson & 1 & 20 & PAS $^{* * *}$ & NS \\
\hline A. "foveata-lg." & & 12 & 5 & $\mathrm{FOR}^{*}$ & WET* \\
\hline A. bireticulata & Rothwell \& Trappe & 1 & 8 & NS & NS \\
\hline A. longula & Spain \& Schenck & - & 6 & PAS* $^{*}$ & NS \\
\hline A. aff mellea & Spain \& Schenck & 2 & 3 & NS & NS \\
\hline A. scrobiculata & Trappe & 1 & 4 & NS & NS \\
\hline A. aff elegans & Trappe \& Gerdemann & 1 & 1 & NS & NS \\
\hline A. "tiny sp." & & - & 2 & NS & NS \\
\hline A. aff spinosa & Walker \& Trappe & 1 & - & NS & NS \\
\hline \multicolumn{6}{|l|}{ Glomaceae } \\
\hline Glomus "sm. brown" & & 56 & 57 & PAS $^{* * *}$ & NS \\
\hline G. occultum & Walker & 28 & 32 & PAS $^{* * *}$ & NS \\
\hline G. "spinosum" & & 14 & 26 & PAS* & NS \\
\hline G. rubiformis & (Gerd \& Trap) Almeida \& Schenck & 13 & 22 & PAS* & NS \\
\hline G. clarum & Nicolson \& Schenck & 5 & 25 & PAS $* * *$ & NS \\
\hline Sclerocystis coremioides & Berkeley \& Broome & 9 & 12 & NS & NS \\
\hline G. leptotichum & Schenck \& Smith & 4 & 15 & PAS* & NS \\
\hline G. clavisporum & (Trappe) Almeida \& Schenck & 5 & 13 & PAS $^{*}$ & NS \\
\hline G. geosporum & (Nicol \& Gerd) Walker & 6 & 2 & NS & NS \\
\hline G. "Ig. brown" & & 2 & 4 & NS & NS \\
\hline G. "tan thin" & & 4 & 1 & NS & NS \\
\hline \multicolumn{6}{|l|}{ Gigasporaceae } \\
\hline Scutellospora pellucida & (Nicol \& Schenck) Walk \& Sand & 17 & 11 & NS & NS \\
\hline Giagaspora sp. & & 14 & 11 & NS & WET* \\
\hline S. calospora & (Nicol \& Gerd) & 1 & 7 & NS & NS \\
\hline G. giganted & (Nicol \& Gerd) Gerd \& Trappe & 2 & - & NS & NS \\
\hline S. coralloidea & (Trap, Gerd, \& Ho) Walk \& Sand & 1 & - & NS & NS \\
\hline
\end{tabular}

more abundant in pasture (hereafter referred to as "pasture" species). In contrast, only one species, $A$. "foveata-lg.," was consistently more abundant in forest.

Sometimes results across all sites differed from results within sites. For five species, spores were more numerous in either pasture or forest within a particular site, but trends were not consistent among sites (Appendix 1). For example, A. foveata was more common in pasture soil at Neguev, Costa Rica, but more common in forest soil at La Union, Nicaragua. Consequently, results were not significant across sites (Table 2). On the other hand, $G$. leptotichum and $G$. rubiformis tended to be more abundant in pasture, but that trend was only significant across all sites (Appendix 1; Table 2).

Spore size and phylogenetic affinity may affect how a species sporulates in response to the conversion of forest to pasture. All 11 of the pasture species were from the generally small-spored families Glomaceae and Acaulosporaceae, while none belonged to the large-spored Gigasporaceae (Table 2). The one species more abundant in forest was an abnormally large member of the Acaulosporaceae $(475 \mu \mathrm{m})$. Across all species, spore size tended to be lower in species that sporulated more in pasture than forest, but that trend was only marginally significant (Fig, 2; $P=0.06, R^{2}=0.15$ ) 


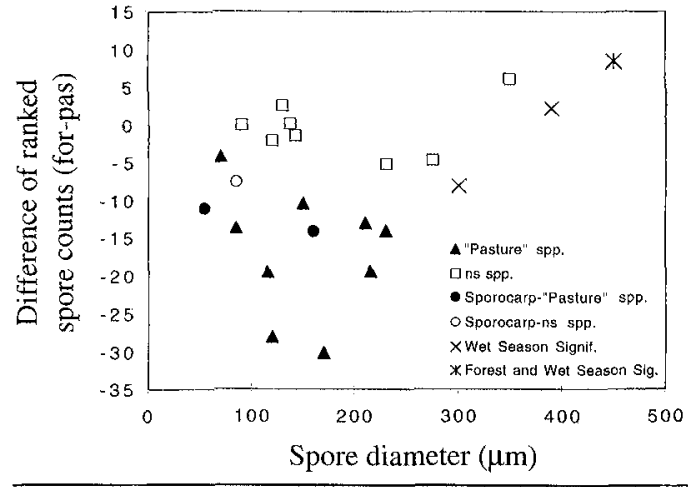

FIGURE 2. Spore size versus abundance in forest and pasture. Y-axis values were determined from the difference in means (forest and pasture) of rank transformed spore counts from each site, averaged over the five sites. Only species found in $>5$ samples are presented. All solid symbols represent "pasture" species (i.e., those significantly more common in pasture; Table 2). Circles represent species in which spores were packed into sporocarps (ca 500 $\mu \mathrm{m}$ each). The Xs are fungi more common in the wet season, while the vertically crossed $X$ represents the largest species, Acaulospora "foveata-lg.," which was more common in both the wet season and in forest soil (Table 2).

SPECIES DIVERSITY.-Depending on which measure of species diversity is emphasized, one could argue that AMF diversity was similar in pasture and forest, or that species richness was greater in forest.

On one hand, pasture and forest contained similar communities of AMF spores. First, from a total of 113 samples, all species present in $>6$ samples were found in both habitats (Table 2). Second, Simpson's diversity indices, calculated from the mean spore numbers at each site, did not differ significantly between habitats $(\bar{x} \pm \mathrm{SE}=1.58 \pm$ 0.43 in forest and $1.87 \pm 0.26$ in pasture; paired $t$-test $P=0.2, N=5$ sites). Third, the most frequently encountered species in forest were generally the most frequent in pasture (Fig. 3a). The only species in which frequencies differed significantly between pasture and forest were $G$. leptotichum and Glomus clarum, both of which were more frequent in pasture (Fig. 3a). Fourth, relative abundance, as percent of total spore volume, did not differ significantly berween habitats for any fungus species (Fig. 3b). Although relative abundance of many large-spored species ( $A$. foveata, $A$. "foveata-lg.," $G i$ gaspora sp., and $G$. gigantea) tended to be lower in pasture, none of those trends was significant. Moreover, in both soil habitats, the Glomus "small brown" complex was clearly the dominant spore type, composing $>60$ percent of the spore volume.

Likewise, local species richness was not reduced in pasture compared to forest. Within each site, $\alpha$ diversity (richness per soil sample) was typically greater in pasture (Fig. 4). This trend was not surprising, given that many species sporulated much more abundantly in pasture. Trends in $\beta$ diversity were not consistent among sites: $\beta$ diversity was significantly higher in forest at Neguev and La Union (Fig. 4a, e), but higher in pasture in the single samples from Finca Meza (Fig. 4c). Most importantly, species richness predicted from species-accumulation curves did not vary consistently among sites (Fig. 4). In four of six graphs (Fig. 4a, $\mathrm{d}-\mathrm{f}$ ), species richness would be greater in forest with further sampling, but the two graphs with the most thorough sampling (Fig. $4 \mathrm{~b}, \mathrm{c}$ ) clearly showed equivalent or higher species richness in pasture. Therefore, based on all of the measures above, local diversity of AMF did not appear to be reduced in pasture compared to forest.

On the other hand, at the regional scale species-accumulation curves indicated that species richness may be greater in forest (Fig. 5). The curves reach an asymptote at 40 species in forest and only 28 species in pasture, a significant difference $(P<0.008)$. In addition, $\beta$ diversity among sites was significantly greater in forest, whether quantified with Sørensen's similarity index ( $t$-test $P$ $=0.007)$ or as the $\beta$ term in the species-accumulation equation $(P<0.008)$. Therefore, at the regional scale, $G$ diversity of AMF spores appeared to be lower in pasture compared to forest.

Seasonality of SPORULATION.-From the three sites that were sampled in both wet and dry seasons, only three morphospecies showed consistent seasonal differences. The spores of $A$. foveata, $A$. "foveata-lg.," and Gigaspora sp. were all significantly more common in the wet season (Table 2). Note that these spore types were among the largest (Fig. 2). In addition, Acaulospora tuberculata, E. aff colombiana, $G$. clarum, and $G$. occultum were each more common in the dry season at a single site, but trends were not consistent across all sites (Appendix 2).

\section{DISCUSSION}

Most of the tropical AMF studied here seemed surprisingly resilient to long-term changes in both host species and abiotic environment. Despite the dramatic changes in host plant species and in soil environment following conversion of forest to pasture, most AM spore populations were not affected negatively. Indeed, many species produced even 

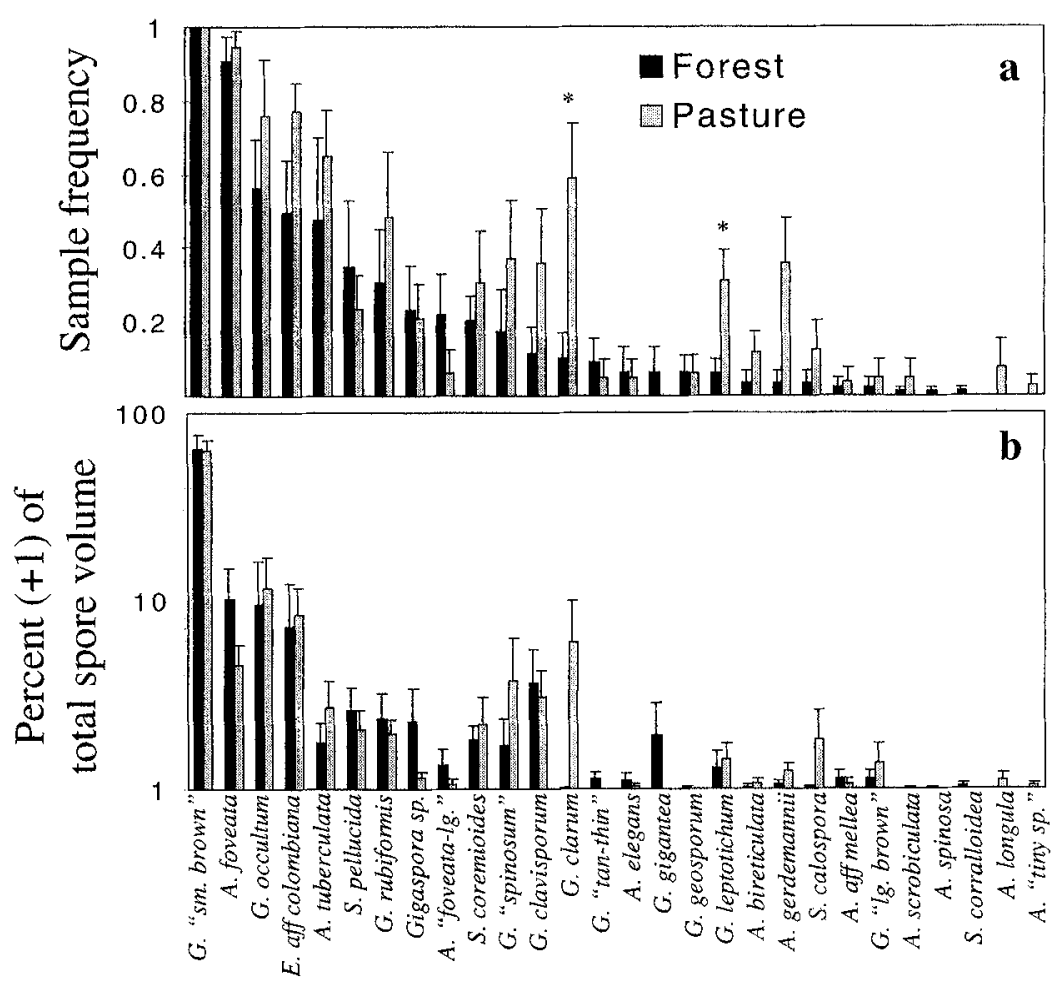

\section{AM fungus species}

FIGURE 3. Dominance-diversity curves for (a) the average frequency of each species and (b) relative abundance among species (determined by spore volume). (a) Species are listed in order of highest to lowest frequency from forest samples. Frequencies were calculated from the proportion of samples that contained each species within each site, which was averaged from all sites $(N=5)$. Columns marked with an asterisk indicate that pasture and forest frequencies differed significantly (paired $t$-test $P<0.05$ ). (b) Relative abundances were calculated from the average percent of total spore volume, also averaged from the five sites. In order to be plotted on a log scale, percent volume was transformed by adding one to each mean value. None of the differences in relative abundance between pasture and forest were significant for any species (paired $t$-test $P>0.05$ ). Bars indicate $\pm S E$.

greater numbers of spores in pastures than in native forest. Although such high sporulation may have indicated that the fungi were stressed in pasture, it also demonstrated that their mycelial biomass was sufficiently abundant to produce a great number of spores. In addition to spore density, the community composition of pasture and forest fungi appeared quite similar, at least at the local scale. Therefore, neither AMF abundance nor diversity appeared limiting in old pastures, and thus mycorrhizal fungi per se should not limit pasture succession and reforestation.

GREATER NUMBERS OF SPORES IN PASTURE.-Total numbers of AMF spores were equal or greater in pasture than in forest soil, which corroborates other studies in the tropics. Total numbers of spores per
$100 \mathrm{ml}$ of soil ( $=c a 100 \mathrm{~g}$ dry wt.) were 110 770 in forest and $830-2600$ in pasture. These counts of whole spores were consistent with previous estimates for humid tropical forest: $250 / 100$ $\mathrm{g}$ dwt. in Cameroon (Musoko et al. 1994); 100300 (live spores) $/ 100 \mathrm{~g}$ dry wt. in Côte d'Ivoire (Wilson et al. 1992); 100-500/100 g fresh wt. in Singapore (Louis \& $\operatorname{Lim} 1987$ ); 200/100 $\mathrm{g}$ soil in cacao forests (Cuenca \& Meneses 1996); and Janos' (1992) general estimate of 50 to 500 spores $/ 100 \mathrm{~g}$ dry wt. Three other studies found spore counts that were an order of magnitude lower than in my study, but in each case, whole spores were more abundant in pasture compared to humid secondary forest in Costa Rica (Fischer et al. 1994), dry forest in Mexico (Allen et al. 1998), or dry jarrah forest in Australia (Jasper et al. 1991). Similarly, undis- 


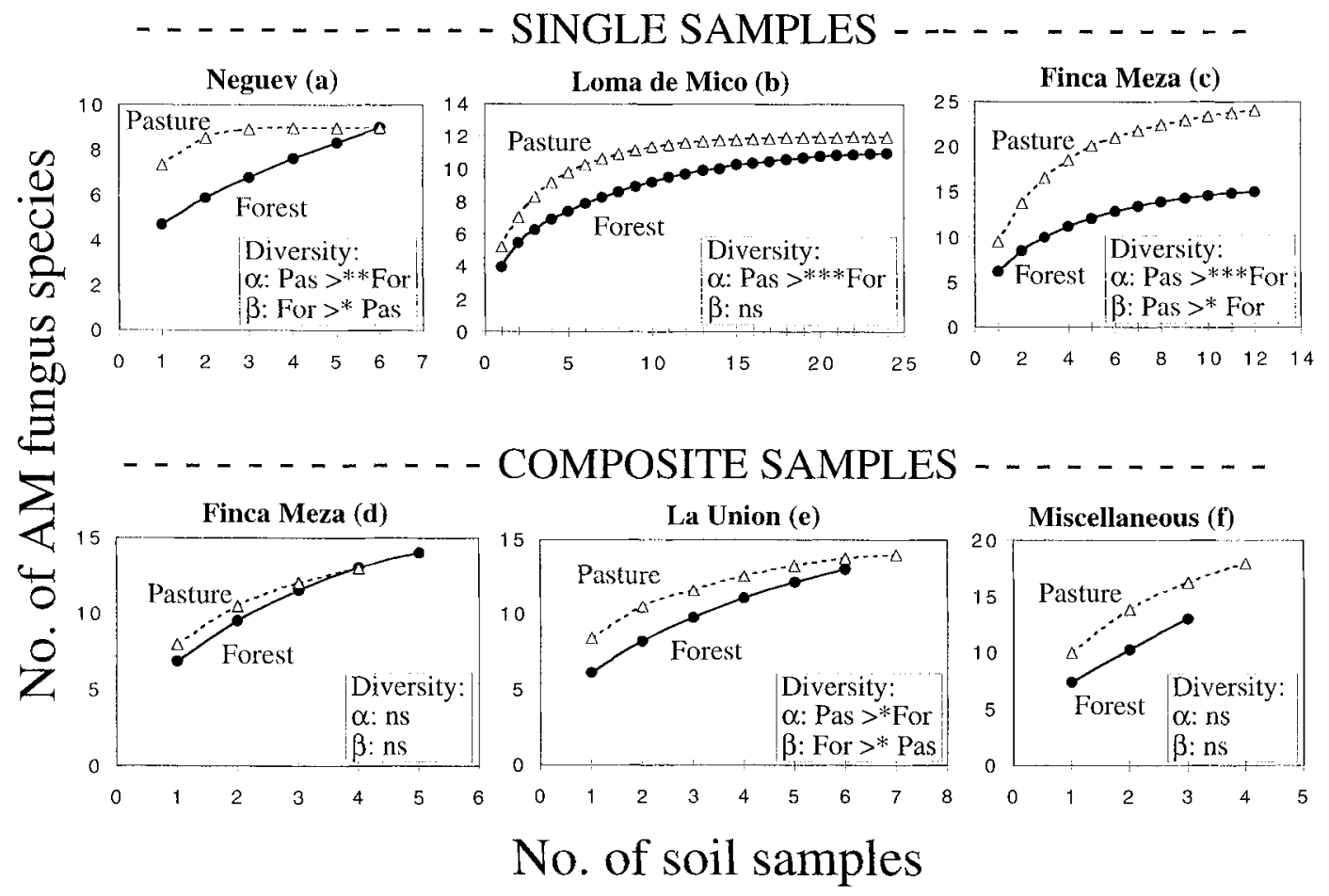

FIGURE 4. Within-site species-accumulation curves: average number of fungal species encountered in one to $N$ samples (single samples or composites). Average was generated from randomly resampling one to $N$ samples for cumulative number of species, reiterated 2000 times. Within-site $\alpha$ diversity is the average species richness in a single sample $(60-300 \mathrm{ml}) ; \beta$ diversity is species change between samples. Pasture and forest $\alpha$ and $\beta$ diversity were compared within each site by $t$-tests: ${ }^{*} P<0.05$; ${ }^{*} P<0.005$; ${ }^{* * *} P<0.0005$.

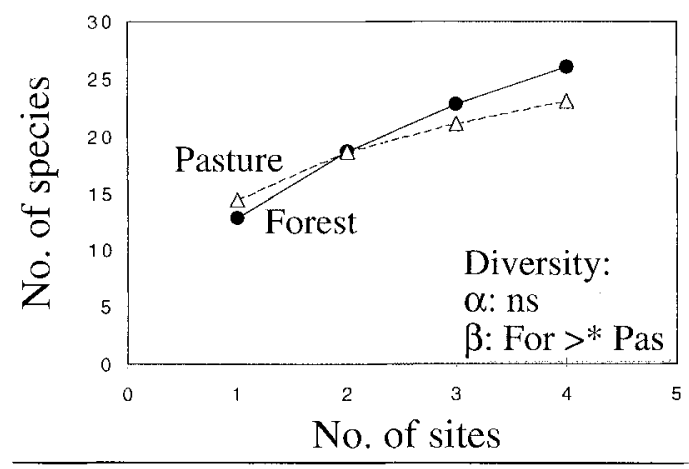

FIGURE 5. Regional species-accumulation curve: average number of fungal species encountered in one to five sites. Regional $\alpha$ diversity is the average species richness in a single site (mean number of species $( \pm S E)$ : pasture $=15.4( \pm 2.4)$, forest $=12.8( \pm 1.5)$; paired $t$-test $P=$ 0.09). Regional $\beta$ diversity is the species turnover between sites. Both $\beta$ and $\mathrm{G}$ diversity (asymptote) were significantly greater in forest than pasture $(P=0.008)$. turbed, infertile savanna in Venezuela had only $150-250$ spores $/ 100 \mathrm{~g}$ soil, while areas revegetated with grasses had $>1000-3000$ spores $/ 100 \mathrm{~g}$ soil (Cuenca \& Lovera 1992, Cuenca et al. 1998). In contrast to the above studies, Johnson and Wedin (1997) found that Costa Rican dry forest had the same high spore abundance as invasive grassland (ca 10,000 spores $/ 100 \mathrm{~g}$ dry soil).

Several hypotheses could explain why many AMF species produced more spores in pasture than in their native forest. First, death or senescence of host plants induced AM fungi to sporulate (e.g., Janos 1992). Because of grazing, fire, and drought, pasture hosts died and senesced more often than forest hosts, which could have increased spore abundance. Second, fine root density was five to nine times greater in pasture than in forest (Picone, pers. obs.). Spore counts thus may have increased as a result of greater availability and turnover of fine roots. Third, soil $\mathrm{pH}$ was higher in pasture (4.8-5.6) than in forest (3.9-4.7). Because AMF species vary in their optimal $\mathrm{pH}$ range, increased $\mathrm{pH}$ may have improved the growth and sporulation 
of some species. Fourth, host-dependent sporulation can influence the relative abundance of AMF spores (Bever et al. 1996). In particular, some of the "pasture" fungi here preferentially sporulated with the shade-intolerant host plants that dominated pasture (Picone 1999), which could have accounted for their increased spore abundance.

Alternatively, removal of spores via decomposition or consumption may have reduced spore abundance more in forest than pasture. Because pasture soil is generally drier than forest soil ( $\mathrm{Pi}$ cone, pers. obs.), high spore counts in pasture could have resulted from slower decomposition rates; however, this explanation is unlikely. Slow decomposition rates in pasture would increase the ratio of dead, empty spores to live, cytoplasmic spores. I compared this ratio from $800 \mathrm{~A}$. foveata and 600 Glomus "sm. brown" spores in pasture and forest from four sites. The proportion with cytoplasmic contents was statistically indistinguishable between the two soil habitats $\left(\chi^{2} P>0.05 ; A\right.$. foveata had 25 percent whole spores in forest and 20 percent in pasture; Glomus "sm. brown" had 18 percent in forest and 16 percent in pasture). In addition, soil sievings $(<500 \mu \mathrm{m})$ from pasture are more infective than forest sievings (Picone, pers. obs.), further supporting the view that high spore counts did not result simply from slow decomposition of dead spores. On the other hand, spore counts could have been influenced by consumption rates because soil arthropods are more abundant in tropical forest than pasture (Lavelle \& Pashanasi 1989). As a consequence, grazing pressure and consumption of AMF spores may be greater in forest.

Although this study did not compare abundance of AM inoculum between pasture and forest, the great abundance of cytoplasmic spores in pasture suggests that plants should encounter sufficient mycorrhizal inoculum there. Of course, spore abundance was not strongly correlated with soil infectivity, because hyphae and infected roots also serve as inocula (Abbott \& Robson 1991, Alexander et al. 1992, Janos 1992). Even so, pasture soil should have extensive fungal mycelia in order to produce such a large number of spores. In support of this view, seedlings can be infected after only five to ten days in pasture soil (Picone 1999). Therefore, restoration of old pastures is unlikely to be limited by insufficient AMF inoculum. These results, however, apply only to old pastures that are dominated by mycorrhizal grasses. In contrast, in highly degraded pastures that are dominated by non-mycorrhizal sedges, growth of transplanted tree seedlings can be greatly improved by artificially inoculating them with AMF (Janos 1988).

Similar COMMUNITY COMPOSITION IN PASTURE AND FOREST. - In addition to the abundance of fungal spores, the species composition of AMF also affects plant growth (van der Heijden et al. 1998a, b). One might predict AMF species richness to decline following conversion of forest to pasture because the fungi encounter a different soil environment, different host plant species, and a tremendous decline in host plant diversity. Most importantly, if only a few, ineffective species were to dominate old pastures, as in some agricultural systems (Sieverding 1989, Johson 1993), then plant succession and restoration would be inhibited.

Diversity of AM fungus spores, however, was surprisingly high in old pasture compared to forest. Out of 113 soil samples, all species present in $>6$ six samples were found in both soil habitats (Table 2). Dominance-diversity curves were fairly similar between both habitats, and relative abundances among species did not differ significantly between pasture and forest for any species (Fig. 3). Simpson's diversity indices, which account for evenness in spore abundance, did not differ between habitats. Local $\alpha$ diversity, or the number of species per soil sample, was consistently higher in pasture (Fig. 4). Both $\beta$ diversity (turnover between samples) and species richness (asymptotes from species-accumulation curves) were higher in pasture at some sites and higher in forest at others, indicating that local species richness generally did not decline following conversion of forest to pasture. Most surprising, even in the large 40-year-old pasture at Loma de Mico, total species richness in pasture was similar to adjacent forest (Fig. 4b).

In contrast to the assessments of species diversity at the local scale, species-site curves at the regional scale indicated that diversity of AMF spores was lower in pasture than forest (Fig. 5). Two advantages to my study were the use of species-accumulation curves and data from multiple, geographically distinct sites. On average, studies that use only one site to compare AMF species richness in forest and pasture would find similar or slightly greater species richness in pasture (Fig. 5). Only after two or three sites are sampled does the regional pattern become clear: total spore diversity is greater in forest. The regional curves reach their asymptotes at 40 species in forest and 28 species in pasture, a significant difference $(P=0.008)$. Likewise, $\beta$ diversity, or species turnover among sites, is significantly greater in forest. 
This regional trend, however, may be an artifact of sampling methods. Any study that assesses AMF spore diversity in the field must add the caveat that counts of field-collected spores only indirectly measure the true diversity and relative abundance of fungus species. Spores are only part of the fungal biomass, which also includes hyphae (extra- and intra-radical), arbuscles, and vesicles. Thus spore counts may overestimate the abundance of species that sporulate heavily in the field, while underestimating species that rarely sporulate. As a consequence, results from fieldcollected spores may differ from results obtained by other methods used to measure AMF abundance, such as trap cultures (Morton et al. 1995, Brundrett et al. 1999) or molecular techniques (e.g., Helgason et al. 1998). In a separate study of AMF diversity in these soils using trap cultures (Picone 1999), no regional decline in AMF diversity was found in pasture, and no such decline appeared at the local scale. Therefore, the trend deserving most emphasis in this study is the high diversity of AMF in tropical pastures compared to forests.

Two other tropical studies reported similar resilience in AMF communities faced with habitat conversion. Johnson \& Wedin (1997) found 24 AMF species in both Costa Rican dry forest and invasive grasslands. In Côte d'Ivoire (Wilson et al. 1992), converting forest to Terminalia plantations increased AMF species richness from 16 to $\mathrm{ca} 30$ species (but more samples were collected in the plantations). In contrast, Sieverding (1989) described several studies in which richness of AMF declined when native ecosystems were converted to agriculture, with 16 to 21 fungus species in soils with natural vegetation, 10 to 15 in lowinput agroecosystems, and only 6 to 9 in intensive agroecosystems. In dry seasonal habitats of Mexico, Allen et al. (1998) reported lower species richness in pasture ( $2 \mathrm{spp}$.) than forest (15 spp.; but fewer soil samples were examined from pasture than forest).

Because of the high AMF diversity in pastures studied here, it seems unlikely that mycorrhizal diversity would limit pasture restoration or reforestation. AMF diversity can influence both plant productivity and species composition (Sieverding 1989, van der Heijden et al. 1998b). From this study of field-collected spores, there is no indication that AMF diversity declines in old pastures compared to native forest (Fig. 4). In fact, young seedlings in pasture soil may be exposed to even more AMF species than seedlings in forest soil, because the number of AMF species in a typical soil sample $(60-300 \mathrm{ml})$ was consistently higher in pasture (Fig. 4). On the other hand, one could argue that a potential decline in species richness at the regional scale (Fig. 5) may influence restoration and reforestation in pastures; however, even if species richness were lower in pasture at a regional scale, the impact on plant community composition would be observable only at an equally broad, regional scale. Given the scale of most restoration efforts, and given the high species richness in pasture soil at each site, a lack of AMF diversity should not limit restoration of old pastures.

SOIL AND SEASONAL PATTERNS ASSOCIATED WITH SPORE SIZE.-The size of a species' spores may relate to its response as the habitat changes from forest to pasture or from wet to dry season (Fig. 2). Species that were most favored by the conversion of forest to pasture generally had smaller spores, although this trend was only marginally significant $(P=$ 0.06 ; Fig. 2). In addition, all pasture species belonged to the Acaulosporaceae or Glomaceae, families with mostly small-spored species (Table 2). The one species more abundant in forest was an atypically large $(450-500 \mu \mathrm{m})$ member of the Acaulosporaceae. Similarly, across all sites, only species with large spores $(300-500 \mu \mathrm{m})$ were more abundant in the wet season.

Both of these trends are consistent with other studies in which large-spored AMF were particularly susceptible to disturbance. Soil cultivation and disturbance have been shown to be most detrimental to the family of AMF with the largest spores, the Gigasporaceae (Rose \& Paranka 1987, Wacker et al. 1990, Miller \& Jastrow 1992, Douds et al. 1993; Cuenca et al. 1998). Converting jarrah forest to pasture favored the small-spored Acaulosporaceae while reducing the Gigasporaceae (Jasper et al. 1991). This trend may be driven by phylogeny, for the Gigasporaceae lack vesicles (Schenck \& Perez 1990 ). Because vesicles store carbohydrates inside roots, root fragments infected by the Gigasporaceae probably lack the energy reserves to serve as propagules; thus this family is more susceptible to soil disturbance. In my study, however, the two largest morphotypes in the Acaulosporaceae showed similar trends as the Gigasporaceae. Therefore, in addition to phylogeny, spore size itself may relate to the response of a species to changes in habitat or season. Likewise, Gould and Hendrix (1998) found that large-spored species succeeded into reclaimed mining soil later than small-spored species. Perhaps 
small-spored fungi were favored by disturbance because they produced more spores than large-spored fungi (Brundrett et al. 1999).

In conclusion, most AMF appeared quite resilient to the conversion of tropical forest into pasture, and in this respect, they may be unique organisms. Such habitat conversion obviously reduces biodiversity of macroorganisms, particularly plants, vertebrates, and insects, and less obviously reduces diversity of soil fauna (Lavelle $\&$ Pashanasi 1989). In contrast, AMF appeared abundant and diverse in pastures. Thus, while many factors can limit plant succession and reforestation in pastures, mycorrhizal fungi are not likely to be one of them.

\section{ACKNOWLEDGMENTS}

For general advice and research design, I am most grateful to D. Janos and J. Bever. D. Janos, M. Bakarr, L. Nicolai, E. Allen, and D. J. Lodge reviewed earlier versions of this manuscript. For assistance in identifying spores, I thank J. Morton, S. Bentivenga, and R. Herrera. Access to research sites was generously provided by the R. Huembes and La Union cooperatives, Carlos Meza, and the Center for Research and Documentation of the Atlantic Coast (CIDCA) in Bluefields, Nicaragua, and by the Tropical Agronomic Center for Investigation and Teaching (CATIE) in Costa Rica. A. Kaufmann, University of Michigan, provided the program to generate species-accumulation curves. This study was supported by a Regents' Fellowship from the University of Michigan, an NSF Graduate Student Fellowship, and NSF grants DSR8971768 and DEB-9524061 to J. Vandermeer.

\section{LITERATURE CITED}

Aввотt, L. K., AND A. D. Robson. 1991. Factors influencing the occurrence of vesicular arbuscular mycorrhizas. Agric. Ecosyst. Environ. 35: 121-150.

Alexander, I. J., N. Ahmad, and L. S. SeE. 1992. The role of mycorrhizas in the regeneration of some Malaysian rainforest trees. Philosophic Trans. R. Soc. Lond. B 335: 379-388.

Alien, E. B., E. Rincón, M. F. Alleen, A. Pérez-Jimenez, and P. Huante. 1998. Disturbance and seasonal dynamics of mycorrhizae in a tropical deciduous forest in Mexico. Biotropica 30: 261-274.

Bever, J. D., J. B. Morton, J. Antonovics, and P. A. Schultz. 1996. Host-dependent sporulation and species diversity of arbuscular mycorrhizal fungi in a mown grassland. J. Ecol. 84: 71-82.

Brundrett, M., L. Abbott, and D. Jasper. 1999. Glomalean mycorrhizal fungi from tropical Australia. I. Comparison of the effectiveness and specificity of different isolation procedures. Mycorrhiza 8: 305-314.

Cuenca, G., Z. De Andrade, and G. Escalante. 1998. Diversity of Glomalean spores from natural, disturbed, and revegetated communities growing on nutrient-poor tropical soils. Soil Biol. Biochem. 30: 711-719.

Sabana, Venezuela. Can. J. Bot. 70: 73-79.

- $\longrightarrow$ AND E. MENESES. 1996. Diversity patterns of arbuscular mycorrhizal fungi associated with cacao in Venezuela. Plant Soil 183: 315-322.

Daniels, B. A., AND H. D. Skipper. 1982. Methods for the recovery and quantitative estimation of propagules from soil. In N. C. Schenck (Ed.). Methods and principles of mycorrhizal research, pp. 29-35. American Phytopathological Society, St. Paul, Minnesota.

Douds, D. D., R. R. JANKE, AND S. E. PETERs. 1993. VAM fungus spore populations and colonization of roots of maize and soybean under conventional and low-input sustainable agriculture. Agric. Ecosyst. Environ. 43: 325-335.

Fischer, C. R., D. P. Janos, D. A. Perry, and R. G. Linderman. 1994. Mycorrhiza inoculum potentials in tropical secondary succession. Biotropica 26: 369-377.

Giller, K. E., M. H. Beare, P. Lavelle, A.-M. N. Izac, and M. J. Swift. 1997. Agricultural intensification, soil biodiversity, and agroecosystem function. Appl. Soil Ecol. 6: 3-16.

Gould, A. B., ANd J. W. Hendrix. 1998. Relationship of mycorrhizal activity to time following reclamation of surface mine land in western Kentucky. II. Mycorrhizal fungal communities. Can. J. Bot. 76: 204-212.

Helgason, T., T. J. Daniei, R. R. Husband, A. H. Fitter, and J. P. W. Young. 1998. Ploughing up the wood-wide web? Nature 394: 431.

JANos, D. P. 1980 . Mycorrhizae influence tropical succession. Biotropica 12: 56-64.

. 1984. Methods for vesicular-arbuscular mycorrhiza research in the lowland wet tropics. In H. A. Mooney, E. Medina, and C. Vasquez-Yanes (Eds.). Physiological ecology of plants of the wet tropics, pp. 173-187. Dr W. Junk, The Hague, The Netherlands.

1988. Mycorrhiza applications in tropical forestry: are temperate zone approaches appropriate? In F. S. P. Ng (Ed.). Trees and mycorrhiza, pp. 133-188. Forest Research Institute, Malaysia, Kuala Lumpur, Malaysia.

1992. Heterogeneity and scale in tropical vesicular-arbuscular mycorrhiza formation. In D. H. Read, D. H. Lewis, A. H. Fitter, and I. J. Alexander (Eds.). Mycorrhizas in ecosystems, pp. 276-282. CAB International, Wallingford, England. 
1996. Mycorrhizas, succession, and the rehabilitation of deforested lands in the humid tropics. In J. C. Frankland, N. Magan, and G. M. Gadd (Eds.). Fungi and environmental change. British Mycological Society Symposium. Cambridge University Press, Cambridge, England.

J Asprer, D. A., L. K. Авbott, and A. D. Robson. 1991. The effect of soil disturbance on vesicular-arbuscular mycorrhizal fungi in soils from different vegetation types. New Phytol. 118: 471-476.

Jornson, N. C. 1993. Can fertilization of soil select less mutualistic mycorrhizae? Ecol. Appl. 3: 749-757.

—- AND D. A. Wrinin. 1997. Soil carbon, nutrients, and mycorrhizae during conversion of dry tropical forest to grassland. Ecol. Appl. 7: 171-182.

Lavelle, P., and B. Pasiranasi. 1989. Soil macrofauna and land management in Peruvian Amazonia (Yurimaguas, Loreto). Pedobiologia 33: 283-291.

Lodge, D. J., D. L. Hawksworti, nnd B. J. Rirchir. 1996. Microbial diversity and tropical forest functioning. In G. H. Orians, R. Dirzo, and J. H. Cushman (Eds.). Biodiversity and ecosystem processes in tropical forests, pp. 69-100. Springer-Verlag, Berlin, Germany.

I.ouls, I., AND G. LIM. 1987. Spore density and root colonization of vesicular-arbuscular mycorrhizas in tropical soil. Trans. Br. Mycol. Soc. 88: 207-212.

Magurlun, A. E., 1988. Ecological diversity and its measurement. Princeton University Press, Princeton, New Jersey.

Mason, P. A., M. O. Musoko, Ano F. T. LAst. 1992. Short-term changes in vesicular-arbuscular mycorrhizal spore populations in Terminalia plantations in Cameroon. In D. H. Read, D. H. Lewis, A. H. Fitter, and I. J. Alexander (Eds.). Mycorrhizas in ecosystems, pp. 261-267. CAB International, Wallingford, England.

Mulier, R. M., AND J. D. JAsikow. 1992. The role of mycorrhizal fungi in soil conservation. In G. J. Bethlenfalvay and R. G. Linderman (Eds.). Mycorrhizae in sustainable agriculture, pp. 29-44. American Society of Agronomy, Madison, Wisconsin.

Mokion, J. B., and G. L. Benny. 1990. Revised classification of arbuscular mycorrhizal fungi (Zygomycetes) —a new order, Glomales, 2 new suborders, Glomineae and Gigasporineae, and 2 new families, Acaulosporaceae and Gigasporaceae, with an emendation of Glomaceac. Mycotaxon 37: 471-491.

- S. P. B tentivencia, anu J. D. Bever. 1995. Discovery, measurement, and interpretation of diversity in arbuscular endomycorthizal fungi (Glomales, Zygomycetes). Can. J. Bot. 73: S25-\$32.

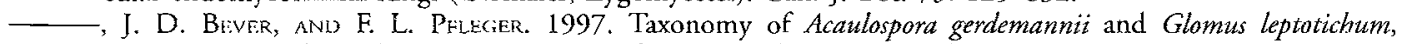
synanamorphs of an arbuscular mycorrhizal fungus in Glomales. Mycol. Res. 101: 625-631.

Musoko, M., F. T. LAST, AND P. A. MASON. 1994. Populations of spores of vesicular-arbuscular mycorrhizal fungi in undisturbed soils of secondary semideciduous moist tropical forest in cameroon. For. Ecol. Manage. 63: 359377.

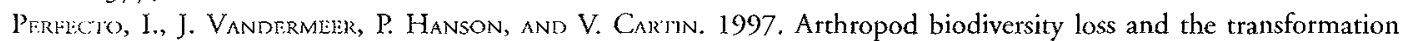
of a tropical agro-cosystem. Biodiv. Conserv. 6: 935-945.

Prcone, C. 1996. Abundance, diversity, and spatial heterogeneity of AM fungal spores in degraded pasture and lowland forest of Nicaragua. In C. Azcón-Aguilar and J. M. Barea (Eds.). Mycorrhizas in inregrated systems: from genes to plant development, pp. 134-136. European Commission, Brussels, Belgium.

1999. Comparative ecology of arbuscular mycorrhizal fungi in lowland tropical forest and pasture. Ph.D. dissertation. University of Michigan, Ann Arbor, Michigan.

Rose, S. L., And J. E. Paranka. 1987. Root and VAM distribution in tropical agricultural and forest soils. In D. M. Sylvia, L. L. Hung, and J. H. Graham (Eds.). Mycorrhizae in the next decade: practical applications and research priorities. 7th North American Conference on Mycorrhizae, p. 56. Institute of Food and Agricultural Science, University of Florida, Gainesville, Florida.

Schenck, N. C., And Y. Perez. 1990. Manual for the identification of VA mycorrhizal fungi. Synergistic Publications, Gainesville, Florida.

Silvtiding, E. 1989. Ecology of VAM fungi in tropical agrosystems. Agric. Ecosyst. Environ. 29: 369-390.

Sir. Join, T. V., AND R. E. Koske. 1988. Statistical treatment of endogonaceous spore counts. Trans. Br. Mycol. Soc. 91: $117-121$.

Stou't, J., and J. Vandermeir. 1975. Comparisons of species richness for stream-inhabiting insects in tropical and mid-latitude streams. Am. Nat. 109: 263-280.

Trapde, J. T. 1987. Phylogenetic and ecologic aspects of mycotrophy in the angiosperms from an evolutionary standpoint. In G. R. Safir (Ed.). Ecophysiology of VA mycorrhizal plants, pp. 5-25. CRC Press, Boca Raton, Florida.

VAN der Hrijden, M. G. A., T. Boller, A. WiemkEN, and I. R. SAnders. 1998a. Different arbuscular mycorrhizal fungal species are potential determinants of plant community structure. Ecology 79: 2082-2091.

- I. N. Kirronomos, M. Ursic, P. Moutoglis, R. Strejtwolf-Engel, T. Boller, A. Wiemken, and I. R. SANDERS. 1998b. Mycorrhizal fungal diversity determines plant biodiversity, ecosystem variability, and productivity, Nature 396: 69-72.

Vandermerr, J. H., M. A. Mallona; D. Boucher, I. Perfecto, and K. Yih. 1995. Three years of ingrowth following catastrophic hurricane damage on the Caribbean coast of Nicaragua: evidence in support of the direct regeneration hypothesis. J. Trop. Ecol. 11: 465-471.

Wacker, T. L., G. R. SAFrR, AND S. StEphenson. 1990. Evidence for succession of mycorrhizal fungi in Michigan asparagus fields. Acta Hortic. 271: 273-278. 
Wilkinson, L., M. Hill, AND E. VANG. 1992. Systat: statistics, version 5.2. Systat, Inc., Evanston, Illinois. Wilson, E. O. 1992. The diversity of life. W. W. Norton, New York, New York.

Wilson, J., K. INGLEby, P. A. MASON, K. IBRAHIM, AND G. J. LAWSON. 1992. Long-term changes in vesicular-arbuscular mycorthizal spore populations in Terminalia plantations in Côte d'Ivoire. In D. H. Read, D. H. Lewis, A. H. Fitter, and I. J. Alexander (Eds.). Mycorrhizas in ecosystems, pp. 268-275. CAB International, Wallingford, England. 
APPENDIX 1. Mean spore abundance of the 28 morphospecies in pasture and forest soil at each site. Species significantly more abundant in pasture or forest soil are indicated by PAS or FOR, respectively. Significance was determined by one-way Kruskal-Wallis tests for each site. In three cases (indicated by superscript ${ }^{2}$ ), seasonal variation in spore number confounded the Kruskal-Wallis tests, so results are presented from two-way resampling tests (season $\times$ soil). ${ }^{*} \mathrm{P}<0.05 ;{ }^{* * \mathrm{P}}<0.005 ;{ }^{* * *} \mathrm{P}<0.0005$.

Number of spores $(\bar{x} \pm S E) / 100-\mathrm{ml}$ soil

\begin{tabular}{|c|c|c|c|c|c|c|}
\hline \multirow{3}{*}{$\begin{array}{c}\text { Species/Spore } \\
\text { Type }\end{array}$} & \multirow{2}{*}{\multicolumn{3}{|c|}{ Neguev }} & \multirow{2}{*}{\multicolumn{3}{|c|}{ Loma de Mico }} \\
\hline & & & & & & \\
\hline & FOR $N=6$ & & PAS $N=6$ & \multicolumn{2}{|l|}{ FOR $N=24$} & PAS $N=24$ \\
\hline$\overline{\text { Acaulosporaceae }}$ & & & - & & & \\
\hline Acaulospora foveata & $0.5( \pm 0.2)$ & PAS $^{* *}$ & $10.8( \pm 3.8)$ & $0.5( \pm 0.1)$ & NS & $1.4( \pm 0.4)$ \\
\hline $\begin{array}{l}\text { Entrophospora aff colom- } \\
\text { biana }\end{array}$ & $92( \pm 33)$ & NS & $136( \pm 70)$ & $0.2( \pm 0.2)$ & PAS ${ }^{* * *}$ & $178( \pm 58)$ \\
\hline A. tuberculata & - & PAS $^{*}$ & $3.4( \pm 2.2)$ & $0.02( \pm 0.02)$ & NS & $0.10( \pm 0.04)$ \\
\hline A. gerdemannii & - & & - & - & $\mathrm{PAS}^{* *}$ & $0.16( \pm 0.07)$ \\
\hline A. "foveata-ly." & - & & - & - & & - \\
\hline A. bireticulata & - & & -- & - & PAS* & $0.20( \pm 0.12)$ \\
\hline A. longula & - & & -- & $\ldots$ & & - \\
\hline A. aff mellea & - & & - & - & & - \\
\hline A. scrobiculata & - & & - & - & & - \\
\hline A. aff elegans & - & & - & - & & - \\
\hline A. "tiny sp." & - & & _- & - & & -- \\
\hline A. aff spinosa & - & & - & - & & - \\
\hline \multicolumn{7}{|l|}{ Glomaceae } \\
\hline Glomus "sm. brown" & $131( \pm 27)$ & PAS* & $1002( \pm 344)$ & $103( \pm 11)$ & $\mathrm{PAS}^{* *}$ & $634( \pm 150)$ \\
\hline G. occultum & $257( \pm 69)$ & PAS* & $4200( \pm 1030)$ & $2.2( \pm 1.0)$ & NS & $0.80( \pm 0.34)$ \\
\hline$G$. "spinosum" & - & & - & $2.1( \pm 1.0)$ & NS & $2.6( \pm 1.0)$ \\
\hline G. rubiformis & - & & - & $0.02( \pm 0.01)$ & NS & $0.05( \pm 0.01)$ \\
\hline G. clarum & - & PAS*** & $253( \pm 129)$ & & PAS* $^{*}$ & $0.6( \pm .04)$ \\
\hline Sclerocystis coremioides & $0.1( \pm 0.1)$ & PAS* & $2.1( \pm 0.7)$ & - & & - \\
\hline G. geosporum & $54( \pm 54)$ & NS & $43( \pm 33)$ & $0.23( \pm 0.17)$ & NS & $0.30( \pm 0.16)$ \\
\hline$G$. leptotichum & - & NS & $2.4( \pm 3.5)$ & - & & - \\
\hline G. clavisporum & - & & - & $0.08( \pm 0.05)$ & NS & \\
\hline G. "lg. brown" & - & & $\ldots$ & - & & - \\
\hline G. "tan thin" & - & & - & $0.14( \pm 0.07)$ & NS & \\
\hline \multicolumn{7}{|l|}{ Gigasporaceac } \\
\hline Scutellospora pellucida & $0.3( \pm 0.3)$ & NS & - & $0.12( \pm 0.04)$ & $\mathrm{FOR}^{* *}$ & $0.01( \pm 0.01)$ \\
\hline Gigaspora sp. & $0.08( \pm .08)$ & NS & -- & - & & - \\
\hline S. calospora & - & & - & - & & - \\
\hline G. gigantea & $0.6( \pm 0.4)$ & NS & - & - & & - \\
\hline S. coralloidea & - & & - & - & & -- \\
\hline
\end{tabular}


APPENDIX I. Extended.

\begin{tabular}{|c|c|c|c|c|c|c|c|c|}
\hline \multicolumn{9}{|c|}{ Number of spores $(\bar{x} \pm \mathrm{SE}) / 100-\mathrm{ml}$ soil } \\
\hline \multicolumn{3}{|c|}{ Finca Meza } & \multicolumn{3}{|c|}{ La Union } & \multicolumn{3}{|c|}{ Miscellaneous } \\
\hline $\begin{array}{c}\text { FOR } \\
N=17\end{array}$ & & $\begin{array}{c}\text { PAS } \\
N=16\end{array}$ & $\begin{array}{c}\text { FOR } \\
N=6\end{array}$ & & $\begin{array}{c}\text { PAS } \\
N=7\end{array}$ & $\begin{array}{c}\text { FOR } \\
N=3\end{array}$ & & $\begin{array}{c}\text { PAS } \\
N=4\end{array}$ \\
\hline $\begin{array}{l}17.8( \pm 4.3) \\
32( \pm 19)\end{array}$ & $\begin{array}{l}\text { NS } \\
\text { PAS }^{* * * *}\end{array}$ & $\begin{array}{l}10.9( \pm 3.8) \\
226( \pm 63)\end{array}$ & $\begin{array}{l}6.9( \pm 1.7) \\
3.4( \pm 2.6)\end{array}$ & $\begin{array}{l}\mathrm{FOR}^{\mathrm{a}^{*}} \\
\mathrm{NS}\end{array}$ & $\begin{array}{l}3.8( \pm 0.9) \\
66( \pm 27)\end{array}$ & $\begin{array}{l}0.7( \pm 0.1) \\
9.0( \pm 9.0)\end{array}$ & $\begin{array}{l}\text { NS } \\
\text { NS }\end{array}$ & $\begin{array}{l}0.6( \pm 0.8) \\
67( \pm 57)\end{array}$ \\
\hline $0.47( \pm .18)$ & $\begin{array}{l}\text { PAS* } \\
\text { PAS* }\end{array}$ & $\begin{array}{l}18( \pm 10) \\
1.9( \pm 1.2)\end{array}$ & $\begin{array}{l}3.4( \pm 1.1) \\
0.36( \pm 0.36)\end{array}$ & $\begin{array}{l}\text { NS } \\
\text { NS }\end{array}$ & $\begin{array}{l}5.3( \pm 2.1) \\
0.39( \pm 0.20)\end{array}$ & $0.8( \pm 0.3)$ & $\begin{array}{l}\text { NS } \\
\text { NS }\end{array}$ & $\begin{array}{l}2.7( \pm 2.1) \\
2.8( \pm 2.0)\end{array}$ \\
\hline $0.50( \pm 0.16)$ & $\mathrm{FOR}^{\mathrm{a} *}$ & $0.2( \pm 0.1)$ & $0.08( \pm 0.08)$ & NS & - & $0.3( \pm 0.3)$ & NS & - \\
\hline - & NS & $0.13( \pm 0.09)$ & $0.08( \pm 0.08)$ & NS & $0.50( \pm 0.42)$ & $\ldots$ & & - \\
\hline - & PAS* & $59( \pm 24)$ & - & & -- & - & & - \\
\hline $9.6( \pm 9.4)$ & NS & $6.2( \pm 6.2)$ & - & & - & - & & - \\
\hline $0.06( \pm 0.06)$ & NS & $0.66( \pm .37)$ & - & & - & - & & - \\
\hline - & & - & - & & - & $0.11( \pm 0.11)$ & NS & $0.13( \pm 0.13)$ \\
\hline - & NS & $48( \pm 32)$ & -. & & - & - & & - \\
\hline $0.06( \pm .06)$ & NS & - & - & & - & - & & 一 \\
\hline $552( \pm 62)$ & PAS** & $1280( \pm 156)$ & $702( \pm 61)$ & PAS** & $2064( \pm 252)$ & $713( \pm 30)$ & PAS* & $2025( \pm 166)$ \\
\hline $6.7( \pm 3.9)$ & NS & $173( \pm 68)$ & $13.1( \pm 8.4)$ & PAS $^{* *}$ & $400( \pm 202)$ & $48( \pm 34)$ & NS & $134( \pm 45)$ \\
\hline - & PAS** & $4.3( \pm 2.4)$ & - & & - & $0.25( \pm 0.25)$ & NS & $177( \pm 176)$ \\
\hline $0.26( \pm 0.15)$ & NS & $2.2( \pm 0.1)$ & $1.2( \pm 0.1)$ & NS & $1.2( \pm 0.4)$ & $0.15( \pm 0.15)$ & NS & $0.9( \pm 0.3)$ \\
\hline $0.08( \pm 0.4)$ & PAS $\mathrm{S}^{\mathrm{a} *}$ & $6.3( \pm 2.8)$ & $0.17( \pm 0.13)$ & PAS* & $26( \pm 13)$ & - & NS & $2.7( \pm 2.5)$ \\
\hline $0.3( \pm 0.1)$ & NS & $0.2( \pm 0.1)$ & $0.03( \pm 0.03)$ & NS & $0.15( \pm 0.13)$ & $0.05( \pm .05)$ & NS & $0.13( \pm 0.13)$ \\
\hline - & NS & $0.08( \pm 0.06)$ & - & NS & $0.06( \pm 0.06)$ & - & NS & $1.8( \pm 1.3)$ \\
\hline $2.4( \pm 1.2)$ & NS & $0.14( \pm 0.08)$ & - & PAS** & $1.9( \pm 0.6)$ & $0.5( \pm 0.5)$ & NS & $2.7( \pm 2.4)$ \\
\hline $2.3( \pm 1.5)$ & NS & $0.32( \pm 0.32)$ & - & & - & - & NS & $0.7( \pm 0.7)$ \\
\hline $3.6( \pm 2.8)$ & NS & $21( \pm 18)$ & - & & - & - & & - \\
\hline- & & - & - & & - & $3.3( \pm 3.3)$ & NS & $0.13( \pm 0.13)$ \\
\hline $0.07( \pm 0.05)$ & NS & $2.2( \pm 1.4)$ & - & NS & $0.40( \pm 0.33)$ & $1.7( \pm 0.4)$ & NS & $2.9( \pm 2.5)$ \\
\hline $1.8( \pm 4.1)$ & NS & $0.28( \pm 0.10)$ & $0.12( \pm 0.08)$ & NS & $0.13( \pm 0.09)$ & - & NS & $0.25( \pm 0.25)$ \\
\hline - & PAS* & $13( \pm 7)$ & $0.9( \pm 0.9)$ & NS & - & - & NS & $0.19( \pm 0.19)$ \\
\hline - & & - & - & & - & - & & - \\
\hline $0.06( \pm 0.06)$ & NS & - & - & & - & - & & - \\
\hline
\end{tabular}




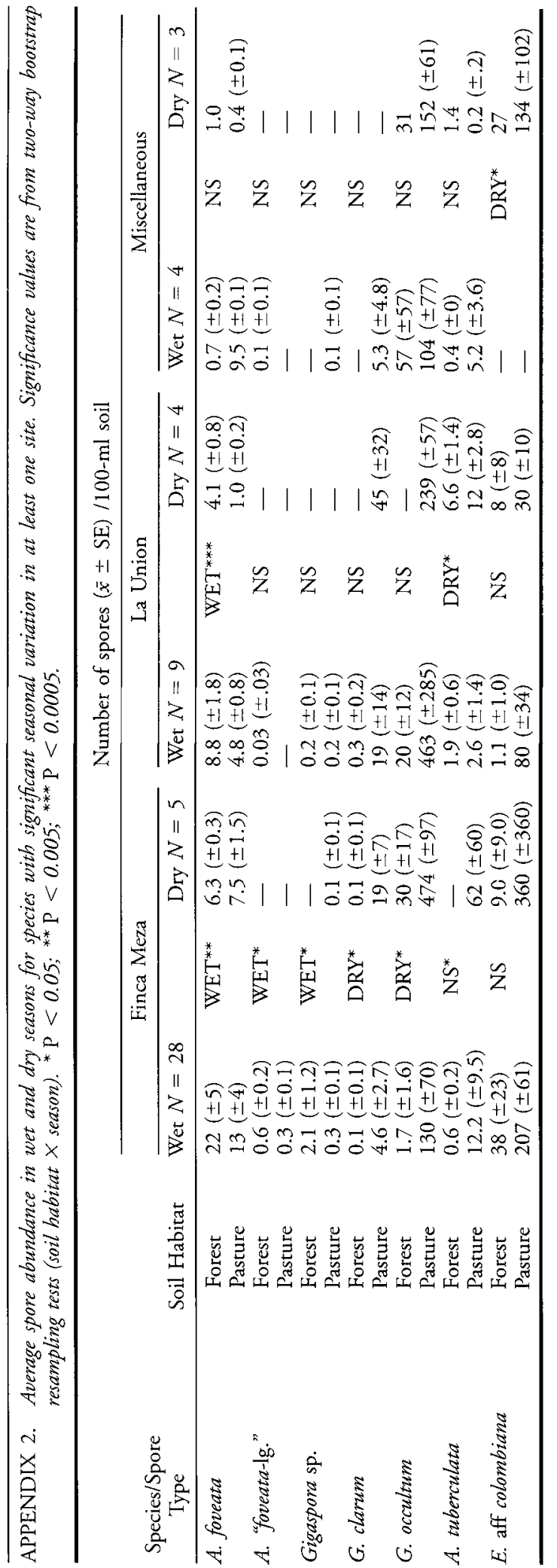

